\title{
Obituary
}

\section{WALTER PAGEL \\ (12 November 1898 to 25 March 1983)}

Walter Pagel was born in Berlin, the son of Julius Leopold Pagel, the well-known medical historian, who contributed numerous articles to August Hirsch's Biographisches Lexikon der hervorragenden Aerzte and who put the study of medieval anatomy and surgery on the map. After a classical philological education, Walter Pagel graduated in medicine in Berlin in 1922. After posts in the Pathology Department of Tübingen University, the Robert Koch Institute, and the Municipal Tuberculosis Hospital in Berlin, he gained a higher doctorate in 1930 at Heidelberg University with a paper on 'Virchow and the principles of medicine during the nineteenth century'. In the same year, his first book on Jan Baptista van Helmont (1579-1644) was published. In 1920, he married Dr Magda Koll, who was to remain dedicated to looking after his well-being and the furtherance of his work to the end of her life in 1980. They had one son, Bernard. In 1933, they emigrated, first to Paris and the Calmette Laboratory at the Pasteur Institute, and then to Cambridge, where Walter Pagel became Pathologist at the Papworth Village Settlement. In 1933, he was one of the founders of the Cambridge History of Science Lectures Committee, and acted as its Honorary Secretary until 1939. He published with Joseph Needham a selection from these lectures entitled Background to modern science, which included Lord Rutherford, Sir Arthur Eddington, and J. B. S. Haldane among its contributors. From 1939 to 1956, he was Consultant Pathologist to the Central Middlesex Hospital, Harlesden, and, from 1956 to 1967, to the Clare Hall Hospital, Barnet, Herts.

His literary and historical work, however, did not start with his retirement in 1967 but had been a continuous activity since his first article on hydranencephaly in 1922 . His standard work on Pulmonary tuberculosis (1939), written originally with G. G. Keyne and L. O'Shaughnessy, has gone into several editions. Indeed, he was acquainted with tuberculosis from personal experience, and, as a result, a delicate state of health constantly dogged his life and restricted his movements considerably but never dampened his exuberant high spirits and sparkling wit nor ever prevented him from continuing with his monumental work. In 1935, his 'Religious motives in medical biology of the seventeenth century', though published in the Bulletin of the History of Medicine, in length really constituted a book. In 1958, his English book on Paracelsus, Paracelsus. An introduction to philosophical medicine in the era of the Renaissance, was published. Another aspect is treated in his German work (1962) on the same subject, Das medizinische Weltbild des Paracelsus. Seine Zusammenhänge mit Neuplatonismus und Gnosis. In 1967, he published William Harvey's biological ideas, presenting Harvey not just as a modern innovator but as a child of his own time. 'William Harvey revisited' in two issues of the annual journal History of Science, 1969/70, nos 8 and 9, and his New light on Harvey of 1976 deal with Harvey's Aristotelianism and with controversies regarding Harvey's discoveries. Even in 1982, Walter Pagel published not only a second revised and enlarged edition of the English Paracelsus book, but also a new book, J. B. Van Helmont, reformer of science and medicine, dealing with Helmont's biological ideas, their sources, background, and 


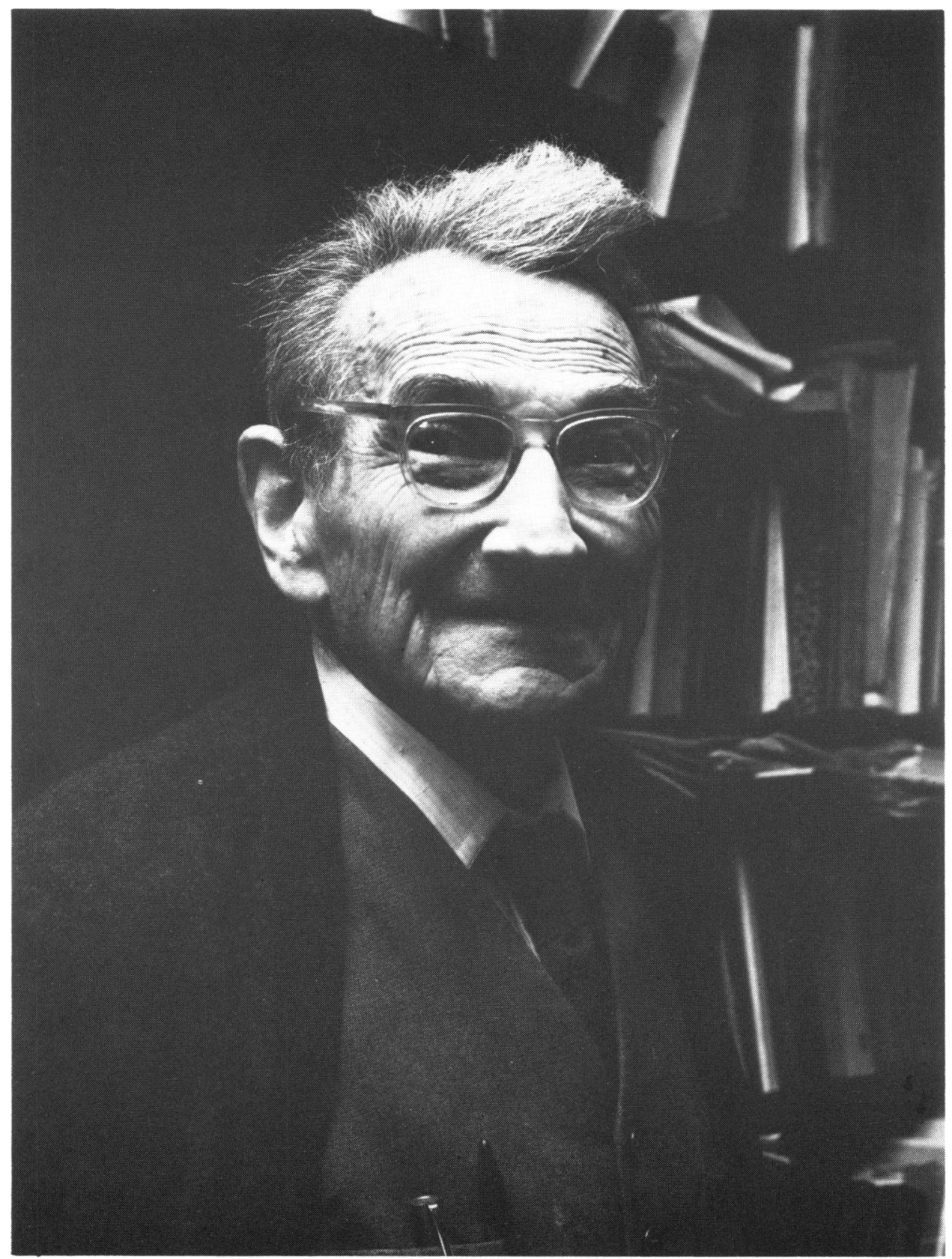

Walter Pagel (1898-1983) at the age of eighty. (Wellcome Institute Library, London.) 


\section{Obituary}

reception. A collection of essays called The smiling spleen will be published shortly. In 1972, a two-volume Festschrift in honour of Walter Pagel's seventieth birthday was published by Neale Watson Academic Publications, edited by Allen Debus and entitled Science, medicine and society in the Renaissance, with articles by outstanding scholars. Its bibliography lists not only the books already mentioned but also over two hundred articles and reviews by Walter Pagel.

However, Walter Pagel's greatness does not consist in the extent of his productivity but in the achievement of having quietly revolutionized the outlook of historians of science and medicine on an international scale. It was he who, over thirty years ago, in an epoch-making paper in the Middlesex Hospital Journal, 1945, 44: 42-45, called 'The vindication of rubbish', said that a medical man or scientist of the past must not be measured against the achievements and requirements of today but must be shown in the context of the philosophy, and religious and intellectual background of his own time, however incongruous with modern views. This paper was the response to a request for a light-hearted contribution to the journal from students, but it and subsequent articles and pronouncements in books by Walter Pagel have changed the face of medical and scientific historiography. Nowadays, the view that theories unacceptable to us have to be included in a truly historical work has become a commonplace. Many people are probably no longer aware that this change of attitude is due to the impetus and constant reminders of Walter Pagel.

He showed in his own work that Harvey's discovery of the circulation of the blood was not merely based on repeated observation but that this observation was preceded by a familiarity with the Aristotelian view of meteorology, in which rain being evaporated into air and air being condensed into water served as a paradigm for biological events. Equally, it was a discovery accompanied by Aristotelian questionings about purpose. Paracelsus, who is usually regarded either as a medieval magus or as the first modern physician who used chemical remedies and rejected humoral pathology, is neither or both. Van Helmont introduced ideas of quantification and specificity that look modern, but he was motivated by the wish to discover the invisible forces that make objects into what they are and without which the material world was to him nothing but dead left-overs.

No wonder, then, if a scholar of such profound insight and a historian with such an original approach was given honorary MD doctorates by Basle (1961) and Heidelberg (1966) universities and a DLitt by the University of Leeds in 1968, the Dexter Award in the History of Chemistry in 1969, the Sarton Medal in 1970, the Julius Pagel Medal in 1971, the Robert Koch Medal in 1973, the William H. Welch Medal in 1976, the Fellowship of the British Academy in 1976 (Pagel was the second medical historian to be so honoured - the first was Joseph Needham), and the Paracelsus ring of the city of Villach in 1978.

Those who had the privilege of knowing Walter Pagel personally could not but feel the kindness of his heart and a deep gratitude for his readiness to encourage anyone wishing to search into problems of their own particular discipline and his ability mysteriously to find relevant material within his own four walls so rarely left by him until his last journey.

MARIANNE WINDER and RENATE BURGESS 